\title{
Landslide Susceptibility Mapping in Brazil: A Review
}

\author{
Helen Cristina Dias ${ }^{1, *} \mathbb{E}$, Daniel Hölbling ${ }^{2}$ a and Carlos Henrique Grohmann ${ }^{1}(\mathbb{D}$ \\ 1 Institute of Energy and Environment, University of São Paulo, São Paulo 05508-010, Brazil; guano@usp.br \\ 2 Department of Geoinformatics-Z_GIS, University of Salzburg, 5020 Salzburg, Austria; \\ daniel.hoelbling@sbg.ac.at \\ * Correspondence: helen.dias@usp.br or helendias71@gmail.com
}

Citation: Dias, H.C.; Hölbling, D.;

Grohmann, C.H. Landslide

Susceptibility Mapping in Brazil: A

Review. Geosciences 2021, 11, 425.

https: / / doi.org/10.3390/

geosciences 11100425

Academic Editors: Matteo Del

Soldato, Lorenzo Solari, Alessandro

Novellino, Hans-Balder Havenith

and Jesus Martinez-Frias

Received: 19 August 2021

Accepted: 12 October 2021

Published: 15 October 2021

Publisher's Note: MDPI stays neutral with regard to jurisdictional claims in published maps and institutional affiliations.

Copyright: (c) 2021 by the authors. Licensee MDPI, Basel, Switzerland. This article is an open access article distributed under the terms and conditions of the Creative Commons Attribution (CC BY) license (https:/ / creativecommons.org/licenses/by/ $4.0 /)$.

\begin{abstract}
Landslide susceptibility studies are a common type of landslide assessment. Landslides are one of the most frequent hazards in Brazil, resulting in significant economic and social losses (e.g., deaths, injuries, and property destruction). This paper presents a literature review of susceptibility mapping studies in Brazil and analyzes the methods and input data commonly used. The publications used in this analysis were extracted from the Web of Science platform. We considered the following aspects: location of study areas, year and where the study was published, methods, thematic variables, source of the landslide inventory, and validation methods. The susceptibility studies are concentrated in Brazil's south and southeast region, with the number of publications increasing since 2015. The methods commonly used are slope stability and statistical models. Validation was performed based on receiver operating characteristic (ROC) curves and area under the curve (AUC). Even though landslide inventories constitute the most critical input data for susceptibility mapping, the criteria used for the creation of landslide inventories are not evident in most cases. The included studies apply various validation techniques, but evaluations with potential users and information on the practical applicability of the results are largely missing.
\end{abstract}

Keywords: mass movements; susceptibility models; landslide; landslide susceptibility; Brazil

\section{Introduction}

Natural hazards are frequent in Brazil, and landslides are considered one of the most common hazards in the country [1-3]. They are responsible for causing losses almost every year, resulting in many economic and social problems. The high frequency of landslides in Brazil is due to natural characteristics such as geomorphology, the tropical climate, and frequent rainfall [3].

Most of rainfall-triggered fatal landslide events in South America are concentrated in Brazil (37\%) [4]. Several high-magnitude events have occurred in the country in the last few decades, most in the south and southeast region [2]. All high-magnitude events were triggered by rainfall and resulted in fatalities and infrastructure damage.

The south and southeast regions of Brazil are the most affected by landslides due to the presence of mountainous areas [3] (Figure 1). The Serra do Mar is the main mountain range near the coast in the south and southeast. Mass movements frequently occur on its steep slopes, resulting in economic and social losses [2]. Important highways cross the area, connecting the plateau to the coastal cities. Thus, landslide susceptibility studies in the Serra do Mar are critical and may help to avoid future losses. The maximum elevation of the Serra do Mar varies from 900-1200 m in São Paulo up to 1800 m in Paraná [5]. Despite having morphological conditions that are favorable to mass movements, the Serra do Mar also presents high values of rainfall. The annual average precipitation for the area is between 1000 and $2000 \mathrm{~mm}$ [3], eventually reaching $5000 \mathrm{~mm}$ when associated with tropical cyclones [1].

Landslide studies in Brazil address several topics related to the process and try to understand under which conditions landslides occur, offering potential mitigation actions 
to avoid future losses. One of the first steps in landslide analysis is the construction of landslide inventories. These inventories can be created by means of different methods (manual, semi-automatic, and automatic) for various purposes, such as the documentation of recent events on the regional or local scale, and as the first step in susceptibility, vulnerability, and risk analysis [6]. Landslide inventories in Brazil are usually created manually through visual image interpretation, without considering standards and common guidelines, and their methodological basis is not addressed frequently in publications [7]. Therefore, guidelines for landslide inventorying are crucial and can influence the accuracy of subsequent analyses based on these inventories.

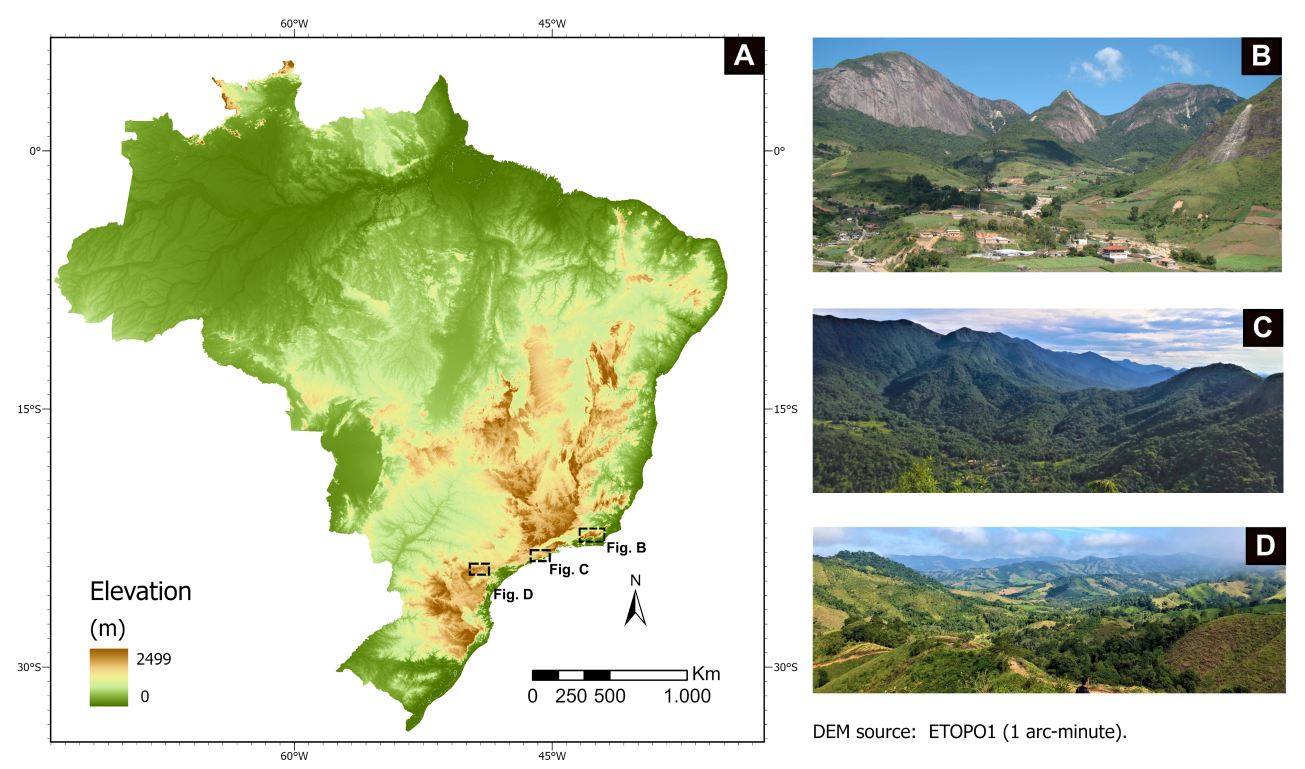

Figure 1. Geomorphological characteristics of Brazil and examples of mountain regions. (A) Elevation of Brazil. (B) Rio de Janeiro mountain range (Source: Marcelo F. Gramani); (C) Serra do Mar in Caraguatatuba, São Paulo; (D) Serra do Mar in Itaóca, São Paulo (source: Vivian Dias).

The susceptibility analysis of landslides is one of the main procedures designed to understand which conditions were responsible for past landslide occurrences, which could generate new landslides in the future [6,8]. Landslide susceptibility refers to the likelihood of landslides to occur in certain conditions (predisposing and triggering factors) on a local or regional scale [9,10], or the tendency of an area to generate landslides [11]. Its determination aims to provide spatial information that helps to prevent future loss of human lives and infrastructure. The analysis is based on the characteristics of the environment and strongly relies on the reliability, accuracy, and completeness of the landslide inventories used. According to Aleotti and Chowdhury [8] the analysis can be qualitative or quantitative, and depends on the aim of the study, the study area, scale, and the data that are available.

Qualitative approaches are based on expert experience and fieldwork [8], whereby the expert is responsible for the selection and mapping of the factors that influence the occurrence of landslides and the weighting of each factor based on personal experience $[12,13]$.

In the quantitative approaches, homogeneous zones are created based on overlay maps and weighted factors with the application of statistical analysis, physically-based models, and machine learning techniques, rather than personal experience [14-19]. In general, quantitative approaches are used when detailed geotechnical information is not available for the whole study area, so the models recognize patterns through computation [8]. Statistical approaches can compare the spatial distribution of landslides to predisposing factors (e.g., morphological and geological factors) and thus identify the most decisive factors for indicating potentially unstable areas. Physically-based models evaluate a local analysis (i.e., of specific sites and slopes) of geotechnical characteristics and the calculation of safety factors (SFs). On the other hand, machine learning techniques rely on algorithms 
that react to training data, which must be capable of learning and create scenarios of susceptibility [20].

Landslide susceptibility studies address several aspects: (1) location—susceptibility analysis is undertaken for areas with previous landslide events, since past events indicate that a particular locality can be susceptible; (2) thematic variables-certain conditions can facilitate or influence landslide occurrence, such as morphological, geological, and geotechnical factors; (3) validation-the final susceptibility map needs to be validated to ascertain if the mapping can be used or not in prevention and mitigation activities.

This paper aims to analyze the methods and input data commonly used in landslide susceptibility mapping in Brazil, via a bibliographic analysis, considering six main criteria: location of the study areas; year of publication and where it was published; susceptibility assessment methods; thematic variables; origin of the landslide inventory; and validation methods.

\section{Materials and Methods}

We applied a systematic search to find publications about susceptibility assessments in Brazil (Figure 2), using one of the main and largest bibliographic repositories commonly used in several geoscience studies [21-24], the Web of Science ${ }^{\mathrm{TM}}(\mathrm{WoS})$, as of April 2021. Journals and other publication media indexed in the WoS need to fulfill several quality criteria; thus, by relying on the WoS it can be expected that the identified articles correspond to a certain scientific standard. Publications not listed in the WoS were not considered in this study since this would have required an extensive manual search, wherein a complete and objective coverage of studies would have hardly been possible.

The keywords applied were "Brazil", "Susceptibility", and "Landslide" for the title, keywords, and abstract of the available publications. The analysis considered only peerreviewed articles and proceedings papers written in English and Portuguese that applied a susceptibility analysis to landslides in the Brazilian territory.

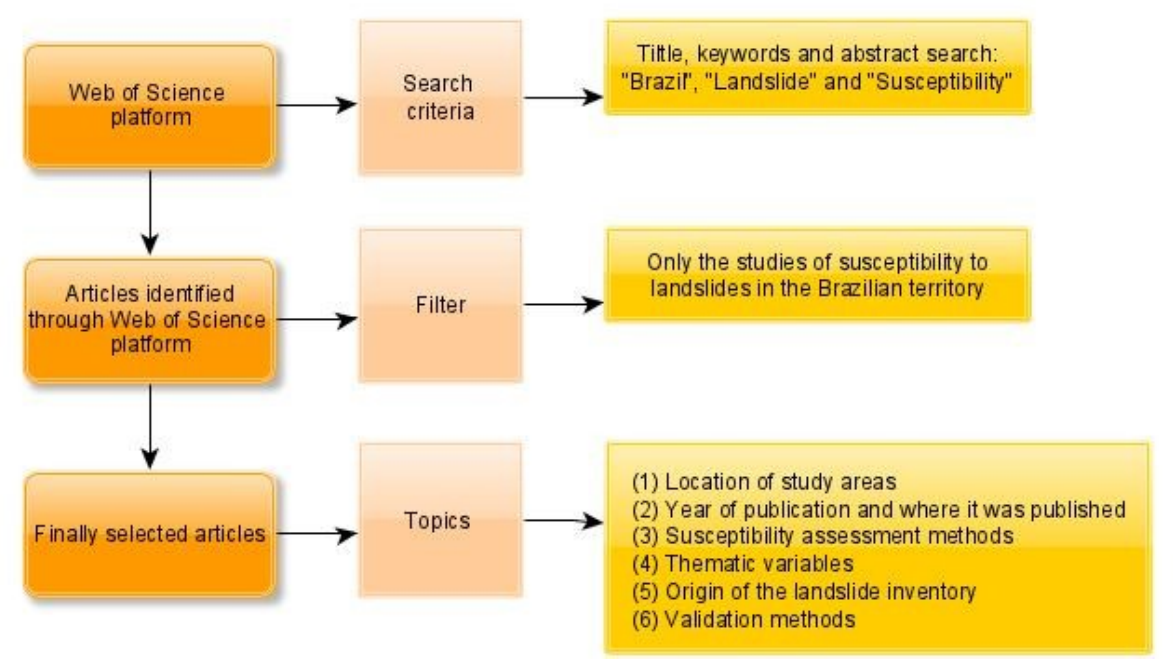

Figure 2. Systematic analysis procedure based on three main steps: search, filtering, and organization of the topics.

Based on our search strategy and criteria, the publications were identified within the WoS platform, and a manual check was performed to verify whether all publications fitted the criteria (Figure 2).

We analyzed the following aspects from the compiled publications: (1) Location of study areas-we collected the name of the federal state of each study area and checked the number of studies per region. (2) Year of publication and where it was published-we identified the year, if the publication was published in a journal or proceedings, and the name of the journal and the event (conference). (3) Susceptibility assessment methodswe collected all the methods and models for the creation of the susceptibility mapping. 
(4) Thematic variables-we collected all variables used for the assessment and organized them into six categories (climatic, geological, geotechnical, hydrological, land cover, and morphological). (5) Origin (source) of the landslide inventory, and if it was constructed specifically for the susceptibility assessment or if the authors used existing inventories. (6) Validation methods-we identified the method used to evaluate the model performance.

\section{Results and Discussion}

The search on the WoS platform resulted in 67 publications. Only 33 were directly related to landslide susceptibility mapping in Brazil. These 33 publications, published in international, in Brazilian journals that publish articles in the Portuguese language as well as in conference proceedings, were considered for further analysis. Several Brazilian journals are not indexed in the WoS, so articles from these journals were not considered in our study.

\subsection{Location of Study Areas}

The study areas of each publication were analyzed based on the federal state of occurrence. Out of the 33 studies analyzed, 19 of them were in the southeast region, in the states of São Paulo (10) [15,25-33], Rio de Janeiro (7) [12,34-39], Minas Gerais (2) [16,40], and Espírito Santo (1) [41]. The remaining 14 were in the south region, in Rio Grande do Sul (8) [14,35,42-47], Santa Catarina (4) [13,48-50], and Paraná (2) [51,52] (Figure 3). Only the article by Bragagnolo et al. [35] had two study areas, one located in Rio Grande do Sul and the other in Rio de Janeiro state.

The primary reason for the concentration of Brazilian landslide susceptibility studies in the southern part of the country is the presence of the Serra do Mar mountain range, located between the states of Rio de Janeiro and Santa Catarina [5]. This region is frequently affected by mass movements (Table 1 and Figure 4), especially the states of Rio de Janeiro and São Paulo, which have together registered more than 3200 deaths due to landslides since 1928 [2].

Table 1. High-magnitude landslide events in Brazil.

\begin{tabular}{lllll}
\hline Location & Year & Rain Amount & Deaths & Reference \\
\hline Caraguatatuba/São Paulo & 1967 & $580 \mathrm{~mm}$ in $48 \mathrm{~h}$ & 120 & {$[2]$} \\
Serra das Araras/Rio de Janeiro & 1967 & $275 \mathrm{~mm}$ in 24 h & 1200 & {$[2]$} \\
Cubatão/São Paulo & 1985 & $380 \mathrm{~mm}$ in $48 \mathrm{~h}$ & 10 & {$[2]$} \\
Santa Catarina & 2008 & $720 \mathrm{~mm}$ in $72 \mathrm{~h}$ & 135 & {$[2]$} \\
Angra dos Reis/Rio de Janeiro & 2010 & $143 \mathrm{~mm}$ in 24 h & 53 & {$[2]$} \\
Itaóca/São Paulo & 2014 & $150 \mathrm{~mm}$ in 6 h & 25 & {$[53]$} \\
\hline
\end{tabular}

\subsection{Year of Publication and Where It Was Published}

The number of publications related to landslide susceptibility mapping in Brazil has increased significantly since 2015 (Figure 5). The first two publications were from 2006 [39,47]. Between 2015 and April 2021, 27 articles were published, comprising about $82 \%$ of the database. According to Reichenbach et al. [54] there has been an increasing global trend of new publications on the susceptibility analysis of landslides starting in the year 2000. In Latin America, the number of studies on landslide hazards has been increasing since 2011 [55]. Brazil is following this regional and global trend (Figure 5).

In the WoS database, there are two types of publication: articles (26) and proceedings papers (7). The proceedings papers were published in English and were from four different conferences: the International Symposium on Landslides (4) [13,33,50,51]; the Lusophone Conference on Sciences and Technologies of Geographic Information (1) [52], the International IAEG Congress (1); and theInternational Conference on Evolution, Monitoring, Simulation, Management and Remediation of the Geological Environment and Landscape (1) [47]. 

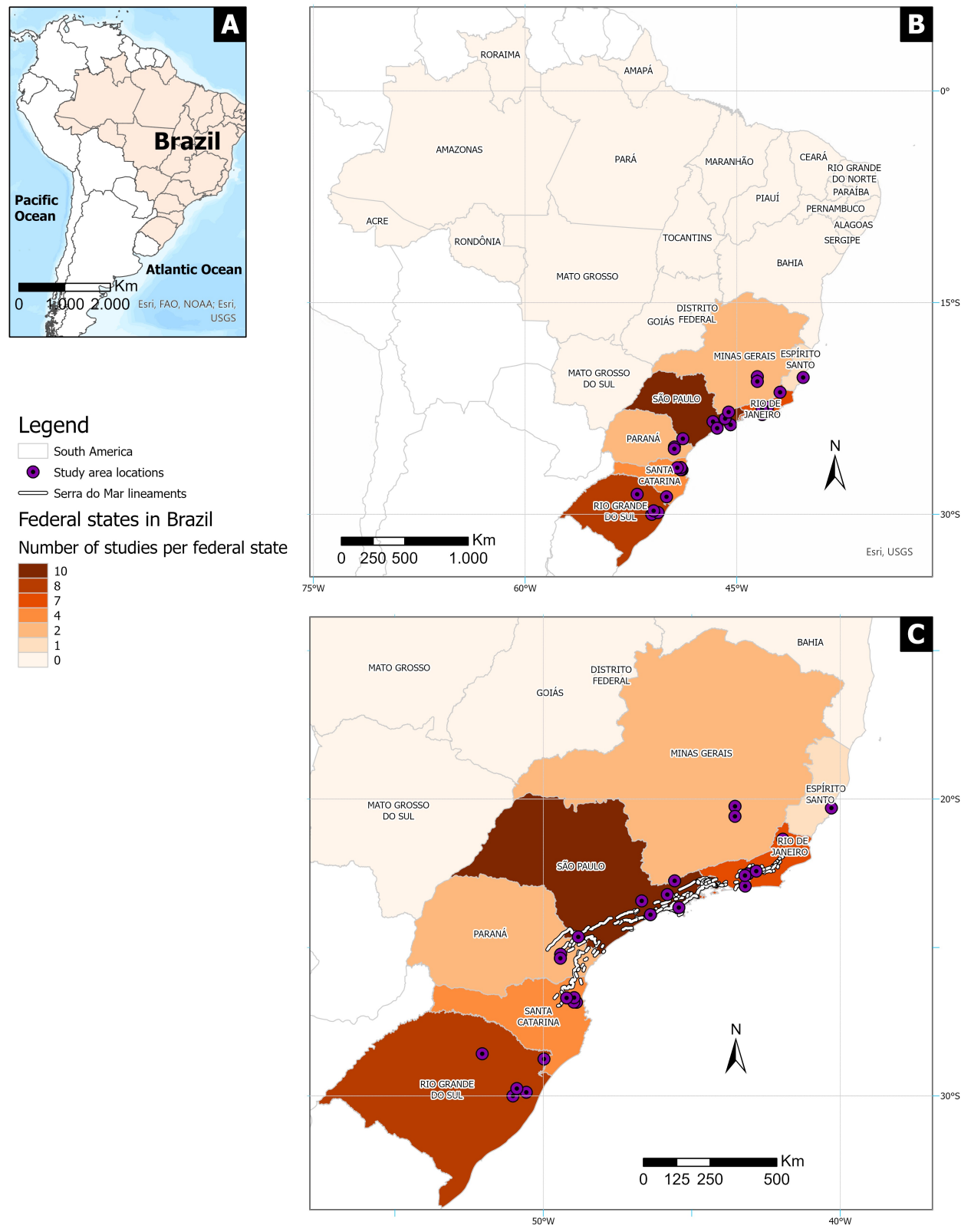

Figure 3. Location of the study areas in Brazil. (A) Overview map of South America; (B) locations (federal states) of the landslide susceptibility studies in Brazil. São Paulo is the state with the highest number of publications (10), followed by Rio Grande do Sul (8), and Rio de Janeiro (7); (C) location of Serra do Mar escarpments and study areas.

The articles were published in 15 different geosciences journals (Figure 5). The journals address several topics, such as geology, geomorphology, and remote sensing. We found that $73 \%$ of the articles were published in international journals in the English language. According to Carrera et al. [55], in Latin America 48.8\% of all publications were in English, followed by Spanish (43.1\%). These numbers show that Brazilian researchers tend to publish in English rather than in Portuguese (the native language). Natural Hazards is the journal with the highest number of publications about susceptibility assessments in Brazil ( $\approx 27 \%$ ), and it is among the five most common journals with publications related to landslides in Latin America [55]. According to Reichenbach et al. [54], Natural Hazards is also one of the journals with the highest number of publications about landslide assessments worldwide. 


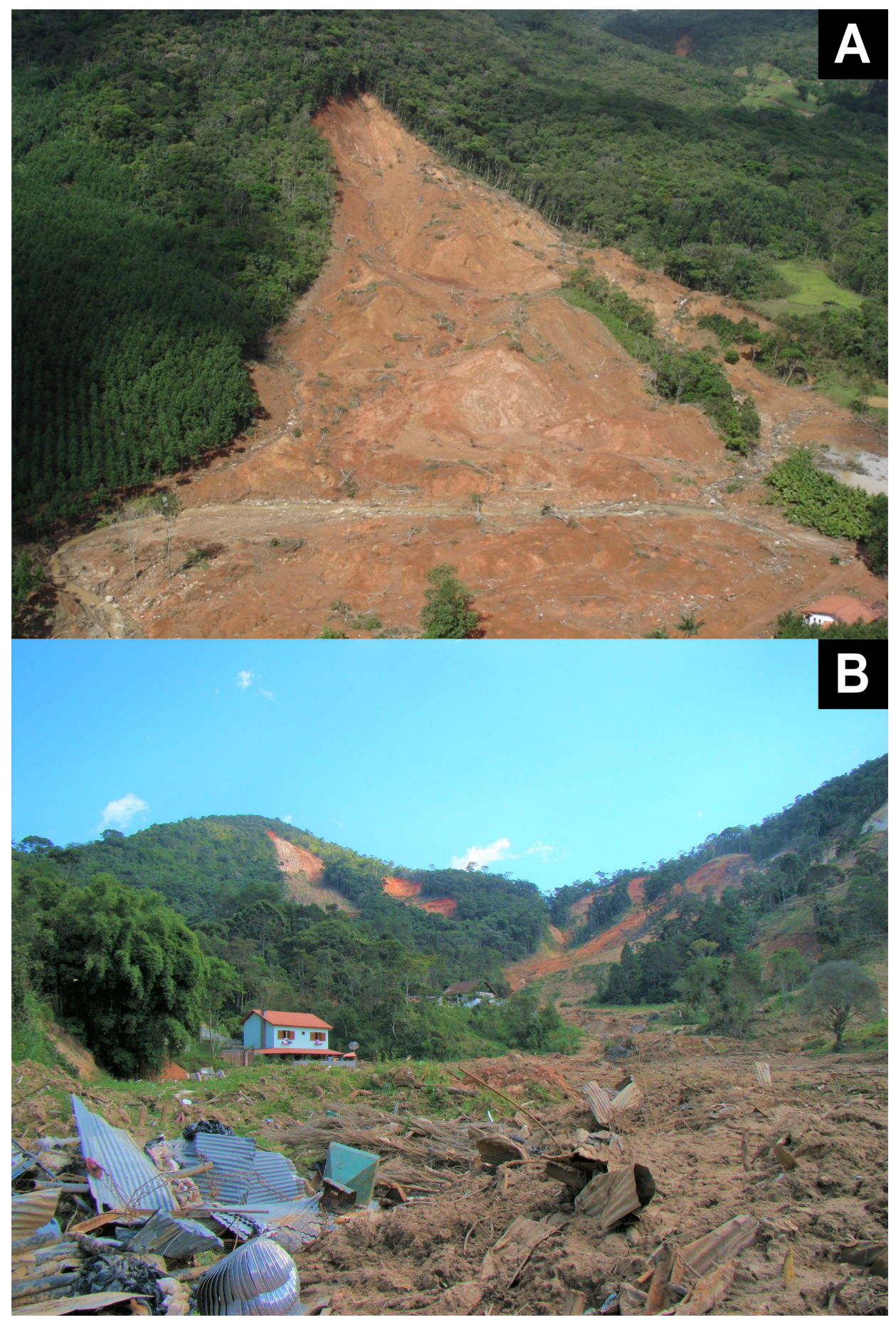

Figure 4. High-magnitude landslide events in Brazil. (A) Landslide in Santa Catarina, 2008 (Source: IPT); (B) Shallow landslides in an inhabited area in Rio de Janeiro mountain range, 2011 (Source: Marcelo F. Gramani).

The remaining $27 \%$ of articles were published in Brazilian journals: GEO UERJ, Anais da Academia Brasileira de Ciências (Annals of the Brazilian Academy of Sciences), and Confins and Revista Brasileira de Geomorfologia (Brazilian Journal of Geomorphology). Only the publication from Anais da Academia Brasileira de Ciências was in English [40]; the other articles were in Portuguese. Revista Brasileira de Geomorfologia is the Brazilian journal with the highest number of publications. 


\subsection{Susceptibility Assessment Methods}

The publications applied 21 different susceptibility model types (Figure 6). About 37\% were slope stability models: the Shallow Landsliding Stability Model (SHALSTAB) (20.9\%), Transient Rainfall Infiltration and Grid-Based Regional Slope Stability (TRIGRS) (9.3\%), Stability Index Mapping (SINMAP) (4.7\%) and Safety Factor FIORI (SF FIORI) $(2.3 \%)$ models. In general, slope stability models use hydrological, geomorphic and geotechnical input parameters, computation of safety factors (SFs), and in some cases they enable the construction of susceptibility scenarios based on rainfall thresholds [49]. SHALSTAB was the most frequently applied model [26-28,31,38,48-51]. It is a physically-based digital terrain model for mapping slope stability potentially related to landslides [56]. Two publications compared some of these models and assessed their performance: Ávila et al. [15] used TRIGRS and SF FIORI and concluded that TRIGRS leads to better results. Vieira et al. [28] compared SHALSTAB and TRIGRS, and concluded that both models were effective in predicting landslides. The first publication applying a slope stability model was published in 2010 [32], and the most recent was published in 2021 [15].

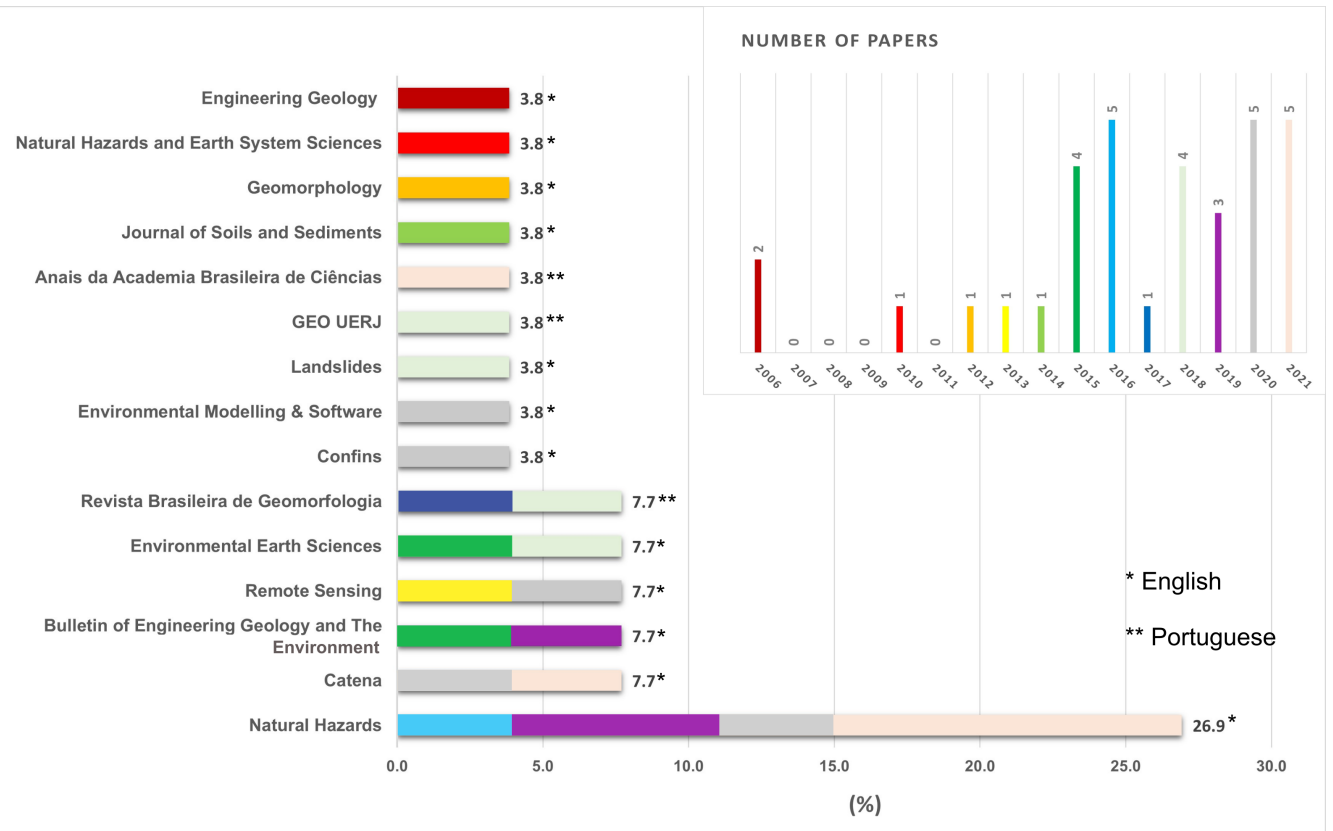

Figure 5. Journals with publications related to susceptibility assessments in Brazil and their year of publication.

Statistical models are also commonly used, such as bivariate analysis, logistic regression, and fuzzy analysis. According to Reichenbach et al. [54], logistic regression analysis counts for $18.5 \%$ of all statistical models applied to landslide susceptibility assessments worldwide. In Brazil, the most frequently applied statistical method is "informative value", a bivariate statistical approach used in landslide susceptibility studies [57], whereas logistic regression analysis has a share of $4.7 \%$. Bivariate statistical analysis calculates the weight of the classes of predisposing factors (e.g., the weight of each rock type in the study area) by landslide density in each class [8]. The first paper that used statistical models for landslide susceptibility mapping in our database was from 2019 [16]. The authors compared several statistical approaches (Bayesian model, informative value, weights of evidence, logistic regression, and discriminant analysis), and the most recent papers that applied these methods were published in 2021 [25,40]. One publication compared the SHALSTAB model and the informative value approach in São Paulo state. The results suggested that the informative value approach shows better performance than SHALSTAB [26]. However, further analysis should be carried out in other regions of Brazil for comparison. 
The application of slope stability models to landslide susceptibility assessments is more common in Brazil, whereas statistical models seem to be becoming more prominent, following the worldwide trend [54].

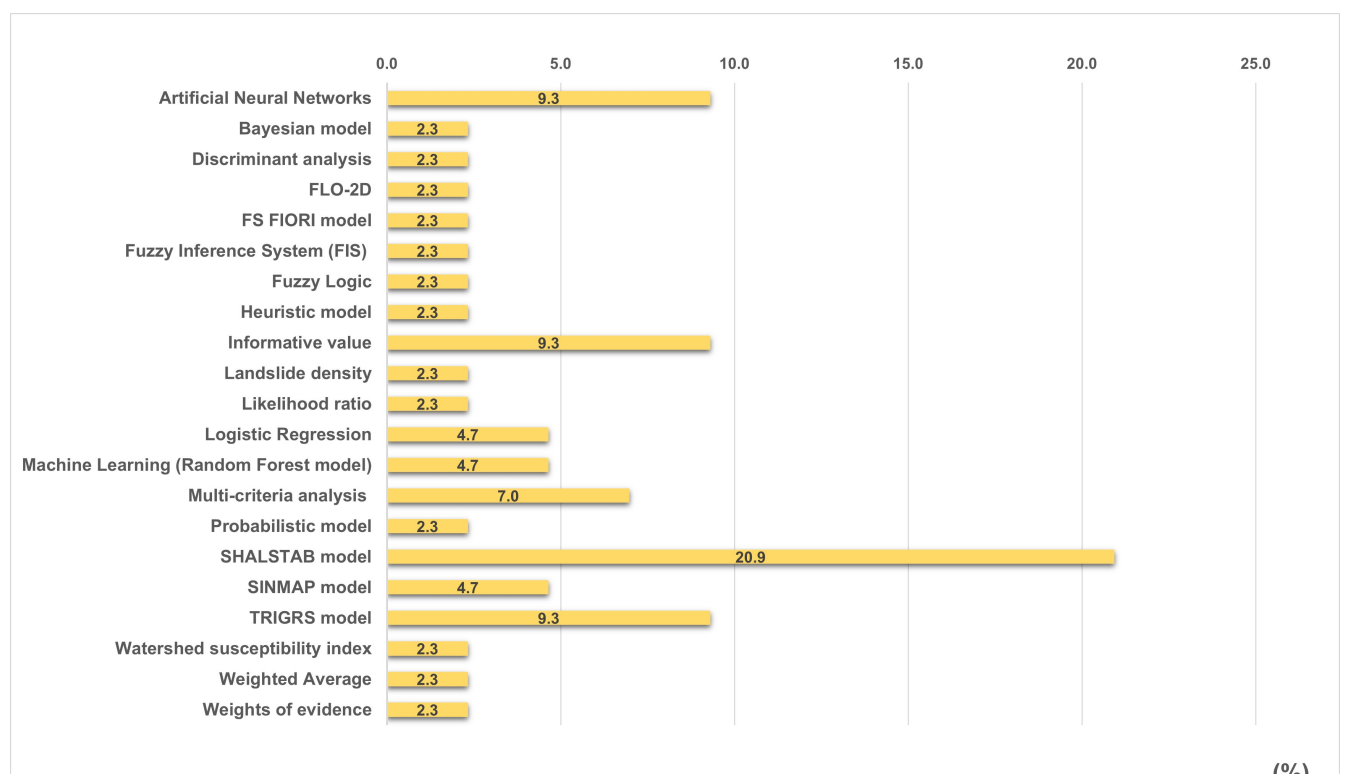

Figure 6. Susceptibility model types used most frequently in Brazil. SHALSTAB is the most common model with $20.9 \%$ of the studies using it.

\subsection{Thematic Variables}

The 60 identified input thematic variables were grouped into six thematic clusters: climatic, geological, geotechnical, hydrological, land cover, and morphological (Figure 7). Some named thematic variables that were considered synonyms were grouped; for example, slope angle, slope gradient, and slope were grouped into slope.

The thematic variable slope was used in approximately $88 \%$ of all publications, followed by aspect $(45.5 \%)$, elevation $(39.4 \%)$, soil cohesion $(36.4 \%)$, and land cover $(33.3 \%)$. Curvature $(27.3 \%)$, profile curvature $(24.2 \%)$, and planar curvature $(18.2 \%)$ were also often used. Mechanical factors presented high percentages, reflecting the results regarding the most frequently used model, discussed in Section 3.3, i.e., SHALSTAB. This model requires mechanical factors, such as soil thickness $(24.2 \%)$, soil friction angle $(21.2 \%)$, and the weight of the soil (18.2\%).

Reichenbach et al. [54] analyzed the thematic variables that are most frequently used worldwide and found that slope was used most often, followed by geo-lithology, aspect, curvature, and land cover. The authors only analyzed papers that applied statistical approaches. Thus, it is impossible to compare the mechanical factors used in Brazil and their worldwide use.

\subsection{Origin of the Landslide Inventory}

Compiling an inventory of landslides is the first step in a susceptibility assessment [6]. Landslide inventories are primary data commonly used to trace the patterns of conditions that may cause landslides in the future. They can be organized based on different perceptions and aims [58,59] and can be used for several purposes, such as landslide documentation on the local or regional scale, or susceptibility, vulnerability, and risk analysis [6]. According to Dias et al. [7] there are no standard guidelines for the construction of landslide inventories in Brazil. Most inventories are constructed manually through visual image interpretation (using aerial photographs, unspecified satellite images, and Google Earth Pro images). Dias et al. [7] identified only six publications about landslide inventory 
mapping in Brazil. Information on the inventories' origin, completeness, accuracy, and up-to-dateness are essential for further analysis, such as landslide susceptibility mapping. However, this type of information is often unavailable, even though the criteria applied to landslide recognition and mapping are essential. The accuracy and reliability of susceptibility mapping results strongly depend on the quality and completeness of the inventory; an inventory with errors can influence the susceptibility analysis, creating distortions [60].

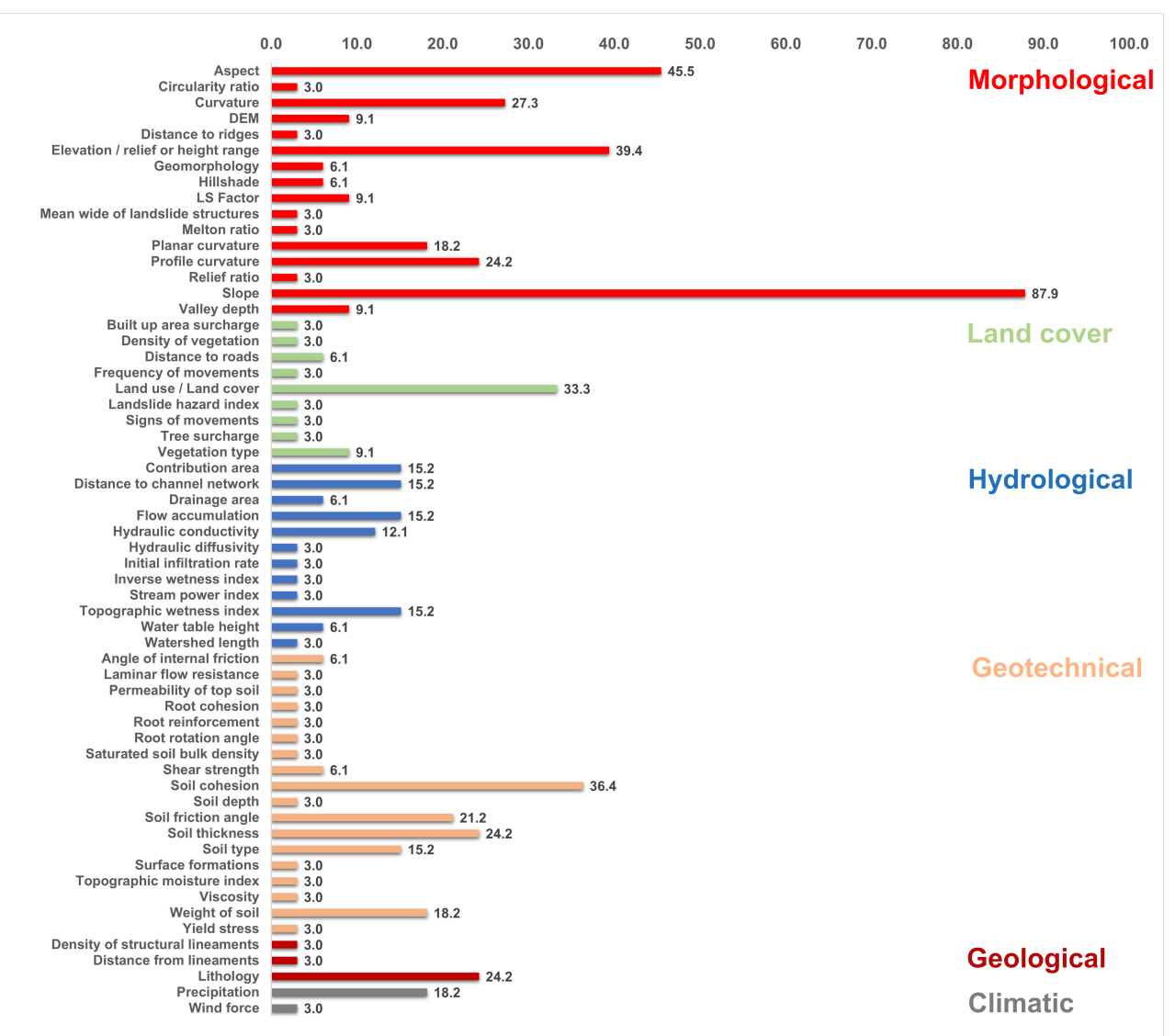

Figure 7. Thematic variables used in landslide susceptibility assessment in Brazil.

We found that $32 \%$ of the landslide susceptibility studies in our database used an inventory of landslides that was based on previous work (Figure 8). The authors generated a new inventory as an input for susceptibility mapping in $56 \%$ of the articles, and $12 \%$ did not mention any inventory in their analysis.

Only a few of the studies that created a new landslide inventory (eight of 19) defined the criteria for the recognition and mapping in the article $[13,16,28,30,32,34,40,49]$. Table 2 shows that there is no standard method for the recognition of landslides in the Brazilian literature. Each publication applied different criteria, and in several cases, the criteria are not clear. The terms "source of the landslide", "where the landslide started", and "rupture area" are examples of criteria that are not clear to the reader, and are subjective. Two publications applied criteria based on the literature [16,40], but they did not specify them. Visual interpretation was applied by five out of eight publications, whereas the other three did not describe how they carried out the recognition. The images used for landslide mapping varied between aerial photographs, orthophotos, satellite images (often without providing specifications), and free high-resolution Google Earth images. König et al. [27] is one example of publication that described the satellite image used: an image from the IKONOS satellite, dated April 2000, two months after the landslide event. Verification of the features during fieldwork was also commonly carried out by the authors $[13,15,16,45,51]$. 


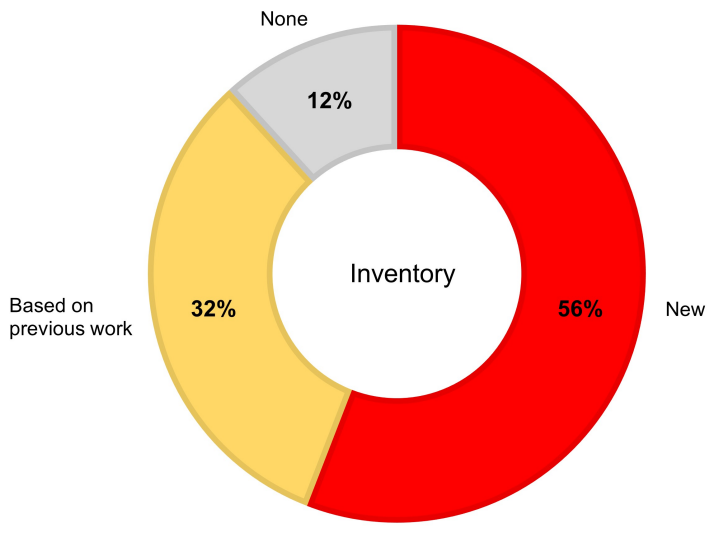

Figure 8. Origin of the landslide inventory used in the reviewed studies.

Table 2. Criteria for the recognition and mapping of landslides in Brazil.

\begin{tabular}{|c|c|c|}
\hline Authors & Criteria & Data \\
\hline Vieira et al., 2010 [32] & $\begin{array}{l}\text { Lighter patches with more con- } \\
\text { trast in texture, and in areas with- } \\
\text { out vegetation (polygons). }\end{array}$ & $\begin{array}{l}1: 25,000 \text { aerial pho- } \\
\text { tographs. }\end{array}$ \\
\hline Michel et al., 2014 [49] & $\begin{array}{l}\text { Only the source of the landslides. } \\
\text { The transport and deposition ar- } \\
\text { eas were not analyzed. }\end{array}$ & $\begin{array}{l}\text { Visual analysis of } \\
\text { orthophotos (1:5000 } \\
\text { scale). }\end{array}$ \\
\hline Nery and Vieira, 2014 [30] & $\begin{array}{l}\text { Scar geometry, absence of vege- } \\
\text { tation, position on the slope, con- } \\
\text { tour lines, and texture analysis. }\end{array}$ & Visual analysis. \\
\hline Tomazzoli et al., 2016 [13] & Rupture area (points). & $\begin{array}{l}\text { Satellite images and } \\
\text { fieldwork. }\end{array}$ \\
\hline Vieira et al., 2018 [28] & $\begin{array}{l}\text { Geometry, absence of vegetation, } \\
\text { contour lines, texture analysis, } \\
\text { and hillslope position. }\end{array}$ & Visual analysis. \\
\hline Barella et al., 2019 [16] & $\begin{array}{l}\text { The recognition of landslide } \\
\text { features was based in part } \\
\text { on Soeters and van Westen } \\
\text { (1996) [61]. Polygons and points } \\
\text { representing centroids in the de- } \\
\text { pletion zones, and fieldwork. }\end{array}$ & $\begin{array}{l}\text { Google Earth Pro im- } \\
\text { ages and Digital Ter- } \\
\text { rain Models (DTM). }\end{array}$ \\
\hline Canavesi et al., 2020 [34] & $\begin{array}{l}\text { The scars were mapped along } \\
\text { their entire length with polygon } \\
\text { geometry, and also as points po- } \\
\text { sitioned where the slide started. }\end{array}$ & $\begin{array}{l}\text { Google Earth images } \\
\text { (visual interpretation), } \\
\text { scientific papers, event } \\
\text { reports provided } \\
\text { by Brazil's National } \\
\text { Center for Monitoring } \\
\text { and Early Warning } \\
\text { of Natural Disasters } \\
\text { (CEMADEN). }\end{array}$ \\
\hline Rosa et al., 2021 [40] & $\begin{array}{l}\text { Based on Rogers and Doyle } \\
\text { (2003) [62]. }\end{array}$ & $\begin{array}{l}\text { Orbital and aerial im- } \\
\text { ages, and fieldwork. }\end{array}$ \\
\hline
\end{tabular}




\subsection{Validation Methods}

The validation of the landslide susceptibility mapping results is the final step in the analysis and enables the comparison of the mapping with other studies in Brazil and worldwide. Nine methods of validation were identified (Figure 9). Sometimes different names were used for the same validation procedure by the authors. We found that $54.1 \%$ of all publications applied area under the curve (AUC) $(27 \%)$, receiver operating characteristic curve (ROC) $(16.2 \%)$, cross tabulation $(8.1 \%)$ and success curve $(2.7 \%)$ analyses.

The first paper that applied statistical validation methods was published in 2015 [52]. Between 2015 and 2021, 27 articles were published and 15 out of them applied cross tabulation [36,52], success curve [26], AUC [14,16,25,35,40,42], ROC [43,46], or AUC/ROC [15,34,44,45] to validate the susceptibility maps. Two publications mentioned validation curves, but did not provide details about them [13,50]. These results demonstrate a growing trend towards the use of these validation methods. Saboya et al. [39] considered only expert opinions to validate the susceptibility mapping, such as those provided by geotechnical engineers and geologists. Publications that did not mention any landslide inventories in their analysis carried out landslide susceptibility validations based on expert assessments [39] or using the risk potential index [31]; four publications did not mention any method of validation [12,33,37,47].

Some of the publications highlight the importance of the developed work and the application of landslide susceptibility studies in Brazil. The authors discuss how the work can be used by research centers, universities, government, and other institutions interested in the prevention, monitoring, and forecasting of landslides [12,15,29,31,33-37,41,43,44,46,50,52]. Vieira et al. [28] mention the importance of models to provide relevant information about areas susceptible to landslides in a cost-efficient manner. However, there was no mention of practical validation with users and local or regional authorities.

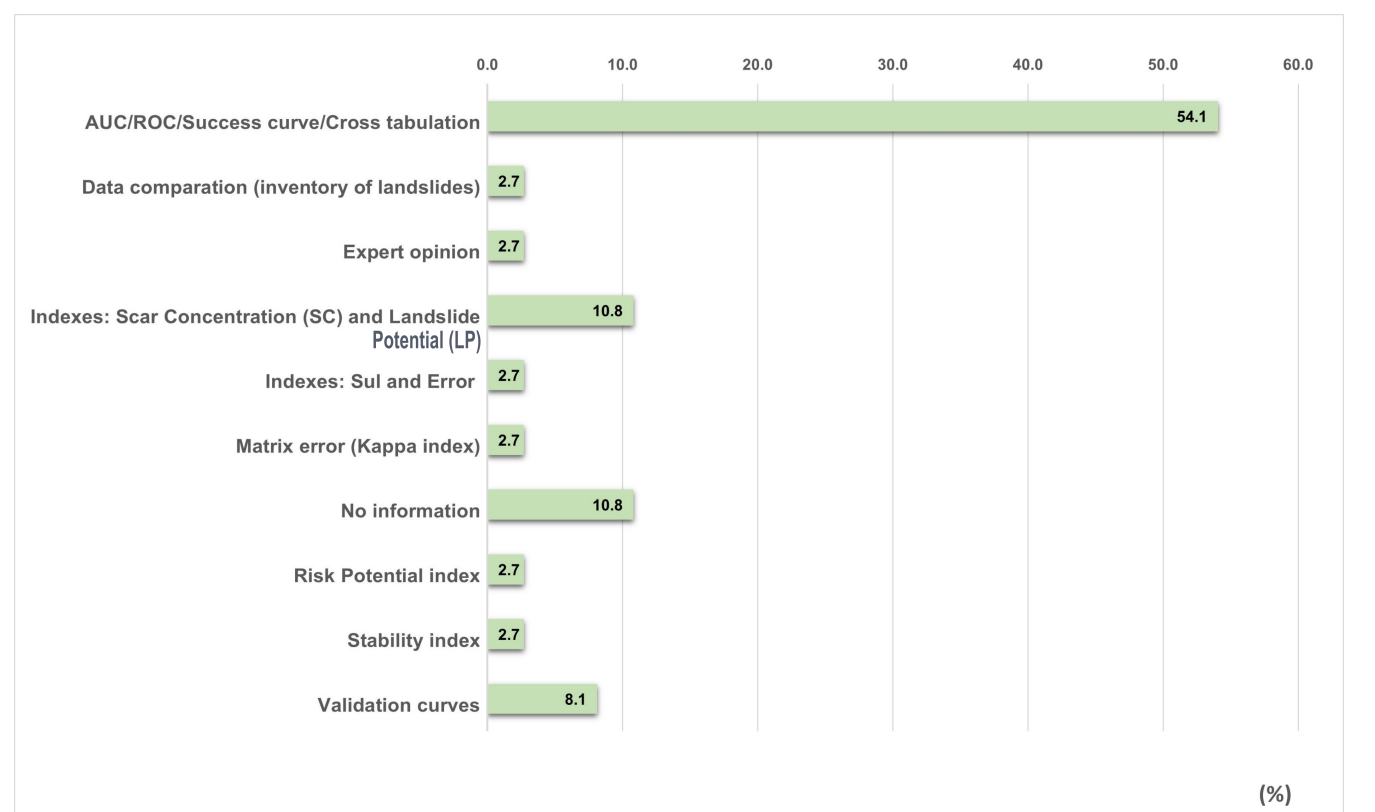

Figure 9. Validation methods used to assess the accuracy of susceptibility maps in Brazil.

\section{Conclusions}

This literature review and analysis enabled us to understand and identify the methods and input data commonly used for landslide susceptibility mapping in Brazil. The results revealed a considerable heterogeneity of methods, thematic variables, the origins of the landslide inventories used, and the validation methods used to assess the final susceptibility maps.

The susceptibility studies were concentrated in Brazil's south and southeast regions due to the very high landslide activity of these areas. Although landslides are also common 
in the proximity of big cities of the northeast region, such as Fortaleza and Salvador, this region was not studied in the identified publications. A reason that could explain this is the absence of high-magnitude events in these regions. The number of publications about landslide susceptibility has increased since 2015, and most of these have been published in international journals in English. The most commonly used methods were slope stability models (e.g., SHALSTAB) and statistical models (e.g., informative value), and the model validation was accomplished using ROC curves and AUC analysis in most publications. The thematic variables vary, but morphological factors were the most common. Slope was used in most publications, followed by aspect and elevation. In more than half of the studies, the landslide inventory was created particularly for the susceptibility analysis. Even though the landslide inventory constitutes the most essential input data for susceptibility mapping, the criteria for the recognition and mapping of landslides were not clarified in most cases. Moreover, the publications that mentioned the landslide inventory mapping criteria presented no standardized guidelines, confirming the findings of Dias et al. [7]. The number of Brazilian studies about landslide susceptibility mapping has been increasing over the last decade, following the global trend. The reviewed studies applied various validation techniques, but there was a lack of validation together with stakeholders and decision-makers to assess the practical applicability of the generated landslide susceptibility maps.

This review lacks studies in the Portuguese language published in journals not indexed in the WoS. Unfortunately, a manual search to identify all existing studies is hardly feasible and is difficult to implement. However, by relying on the WoS database, we believe that we were able to provide a comprehensive overview of landslide susceptibility mapping in Brazil. It is recommended that more Brazilian journals seek international indexing in reputable citation databases, in order to promote the dissemination of Brazilian research.

For future studies, it is suggested that landslide susceptibility analysis should also be carried out for other regions of the country, and not only in the south and southeast regions. It is also recommended that studies should provide details about the landslide inventory used and its construction, since the resulting susceptibility maps strongly rely on these input data.

Author Contributions: Conceptualization: H.C.D. and D.H.; methodology, H.C.D. and D.H.; formal analysis, H.C.D.; investigation, H.C.D.; resources, H.C.D. and D.H.; data curation, H.C.D.; writing—original draft preparation, H.C.D.; writing—review and editing, H.C.D., D.H. and C.H.G.; visualization, H.C.D., D.H. and C.H.G.; supervision, D.H. and C.H.G.; project administration, H.C.D. and C.H.G.; funding acquisition, H.C.D., D.H. and C.H.G. All authors have read and agreed to the published version of the manuscript.

Funding: H.C.D. is supported by FAPESP (The São Paulo Research Foundation) (grant \#2019/172618); D.H. is supported by the Austrian Research Promotion Agency (FFG) in the Austrian Space Applications Programme (ASAP) through the project MontEO (contract \#873667); C.H.G. is supported by FAPESP (grant \#2019/26568-0) and CNPq (grants \#304413/2018-6 and \#423481/2018-5). This study was financed in part by CAPES Brasil-Finance Code 001.

Institutional Review Board Statement: Not applicable.

Informed Consent Statement: Not applicable.

Data Availability Statement: The raw data required in this study are available upon request by contacting H.C.D. (helen.dias@usp.br).

Acknowledgments: We would like to acknowledge the Editor-in-Chief and the anonymous reviewers for their criticism and suggestions, which have helped to improve this paper.

Conflicts of Interest: The authors declare no conflict of interest. 


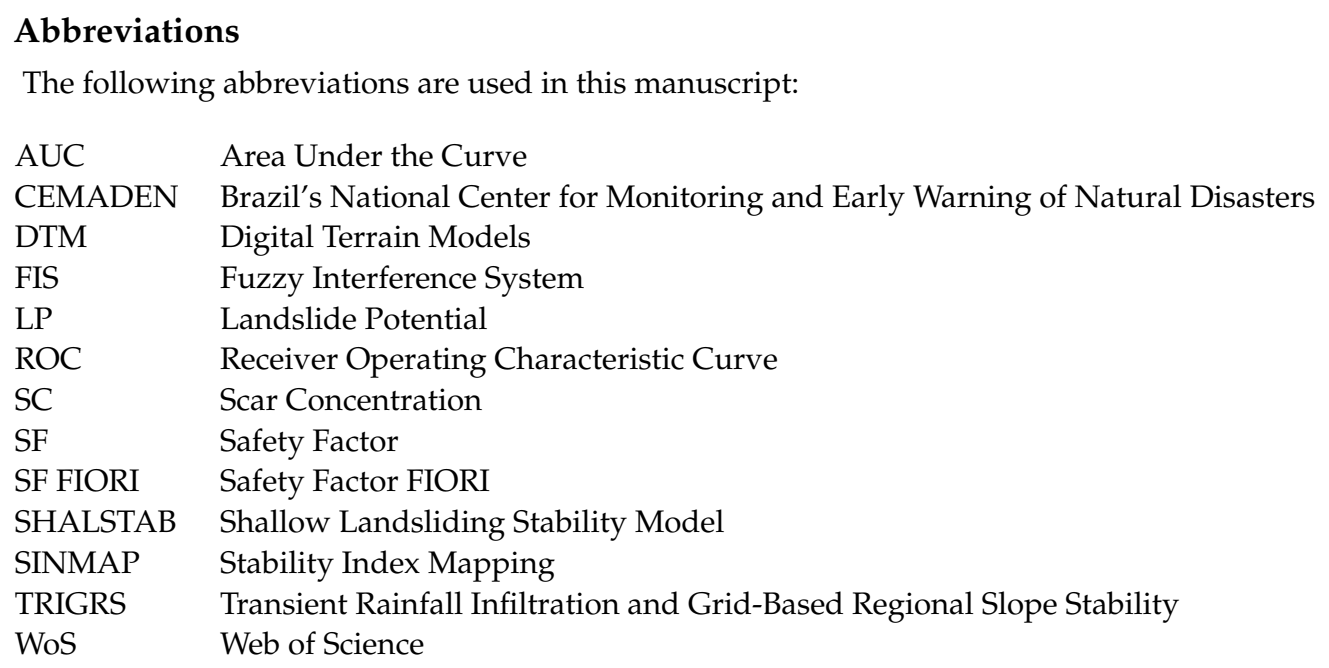

\section{References}

1. Coelho-Netto, A.L.; de Souza Avelar, A.; Lacerda, W.A. Landslides and Disasters in Southeastern and Southern Brazil. Dev. Earth Surf. Process. 2009. [CrossRef]

2. Vieira, B.C.; Gramani, M.F., Serra do Mar: The most tormented relief in Brazil. In Landscapes and Landforms of Brazil; Springer: Berlin/Heidelberg, Germany, 2015; pp. 285-297.

3. IBGE. Suscetibilidade a Deslizamentos do Brasil: Primeira Aproximação; Technical Report; Instituto Brasileiro de Geografia e Estatística: Rio de Janeiro, Brazil, 2019.

4. Froude, M.J.; Petley, D.N. Global fatal landslide occurrence from 2004 to 2016. Nat. Hazards Earth Syst. Sci. 2018, 18, $2161-2181$. [CrossRef]

5. Almeida, F.; Carneiro, C. Origem e Evolução da Serra do Mar. Rev. Bras. Geociências 1998, 28, 135-150. [CrossRef]

6. Guzzetti, F.; Mondini, A.C.; Cardinali, M.; Fiorucci, F.; Santangelo, M.; Chang, K.T. Landslide inventory maps: New tools for an old problem. Earth-Sci. Rev. 2012, 112, 42-66. [CrossRef]

7. Dias, H.C.; Hölbling, D.; Grohmann, C.H. Landslide Inventory Mapping in Brazil: Status and challenges. In Proceedings of the XIII Internacional Symposium on Landslides, Cartagena, Colombia, 22-26 February 2021.

8. Aleotti, P.; Chowdhury, R. Landslide hazard assessment: Summary review and new perspectives. Bull. Eng. Geol. Environ. 1999, 58, 21-44. [CrossRef]

9. van Westen, C.J.; Rengers, N.; Soeters, R. Use of Geomorphological Information in Indirect Landslide Susceptibility Assessment. Nat. Hazards 2003, 30, 399-419. [CrossRef]

10. Corominas, J.; van Westen, C.; Frattini, P.; Cascini, L.; Malet, J.P.; Fotopoulou, S.; Catani, F.; Van Den Eeckhaut, M.; Mavrouli, O.; Agliardi, F.; et al. Recommendations for the quantitative analysis of landslide risk. Bull. Eng. Geol. Environ. 2014, 73, 209-263. [CrossRef]

11. Guzzetti, F.; Reichenbach, P.; Ardizzone, F.; Cardinali, M.; Galli, M. Estimating the quality of landslide susceptibility models. Geomorphology 2006, 81, 166-184. [CrossRef]

12. Silva, L.T.; Sampaio, E.P.F.F.M.; Corte-Real, J.A.M.; Rodriguez, D.A.; Medeiros, F.C.; Moraes, B.E.; França, D.G.M. Susceptibility and Vulnerability to Landslides-Case Study: Basin of River Bengalas-City of Nova Friburgo-Brazil. In Engineering Geology for Society and Territory, VOL 1: Climate Change and Engineering Geology; Springer: Berlin/Heidelberg, Germany, 2015; pp. 539-546. [CrossRef]

13. Tomazzoli, E.; Pellerin, J.; Parizoto, D.; Bonachea, J.; Remondo, J.; Cendrero, A. Comparative analysis of heuristic and probabilistic landslide susceptibility models on the basis of a MORLE. In Landslides and Engineered Slopes: Experience, Theory and Practice; CRC Press: Naples, Italy, 2016; Volume 1-3, pp. 1913-1920. [CrossRef]

14. Lucchese, L.V.; de Oliveira, G.G.; Pedrollo, O.C. Investigation of the influence of nonoccurrence sampling on landslide susceptibility assessment using Artificial Neural Networks. Catena 2021, 198, 105067. [CrossRef]

15. Ávila, F.F.; Alvalá, R.C.; Mendes, R.M.; Amore, D.J. The influence of land use/land cover variability and rainfall intensity in triggering landslides: A back-analysis study via physically based models. Nat. Hazards 2021, 105, 1139-1161. [CrossRef]

16. Barella, C.F.; Sobreira, F.G.; Zêzere, J.L. A comparative analysis of statistical landslide susceptibility mapping in the southeast region of Minas Gerais state, Brazil. Bull. Eng. Geol. Environ. 2019, 78, 3205-3221. [CrossRef]

17. Ngo, P.T.T.; Panahi, M.; Khosravi, K.; Ghorbanzadeh, O.; Karimnejad, N.; Cerda, A.; Lee, S. Evaluation of deep learning algorithms for national scale landslide susceptibility mapping of Iran. Geosci. Front. 2020, 12, 505-519.

18. Alonso, E.E. Triggering and motion of landslides. Géotechnique 2021, 71, 3-59. [CrossRef]

19. Troncone, A.; Pugliese, L.; Lamanna, G.; Conte, E. Prediction of rainfall-induced landslide movements in the presence of stabilizing piles. Eng. Geol. 2021, 288, 106143. [CrossRef]

20. Lees, B.G. Neural network applications in the geosciences: An introduction. Comput. Geosci. 1996, 22, 955-957. [CrossRef] 
21. Gokceoglu, C.; Sezer, E. A statistical assessment on international landslide literature (1945-2008). Landslides 2009, 6, 345-351. [CrossRef]

22. Merghadi, A.; Yunus, A.P.; Dou, J.; Whiteley, J.; ThaiPham, B.; Bui, D.T.; Avtar, R.; Abderrahmane, B. Machine learning methods for landslide susceptibility studies: A comparative overview of algorithm performance. Earth-Sci. Rev. 2020, $207,103225$. [CrossRef]

23. Moayedi, H.; Mosallanezhad, M.; Rashid, A.S.A.; Jusoh, W.A.W.; Muazu, M.A. A systematic review and meta-analysis of artificial neural network application in geotechnical engineering: Theory and applications. Neural Comput. Appl. 2020, 32, 495-518. [CrossRef]

24. Monge, J.J.; McDonald, N.; McDonald, G.W. A review of graphical methods to map the natural hazard-to-wellbeing risk chain in a socio-ecological system. Sci. Total Environ. 2021, 803, 149947. [CrossRef] [PubMed]

25. Dias, H.C.; Gramani, M.F.; Grohmann, C.H.; Bateira, C.; Vieira, B.C. Statistical-based shallow landslide susceptibility assessment for a tropical environment: A case study in the southeastern Brazilian coast. Nat. Hazards 2021. [CrossRef]

26. Bonini, J.E.; de Meneses Bateira, C.V.; Dias, V.C.; Martins, T.D.; Vieira, B.C. Suscetibilidade a escorregamentos rasos a partir de parâmetros morfométricos e dos modelos SHALSTAB e do Valor Informativo. Confins 2020. [CrossRef]

27. König, T.; Kux, H.J.H.; Mendes, R.M. Shalstab mathematical model and WorldView-2 satellite images to identification of landslide-susceptible areas. Nat. Hazards 2019, 97, 1127-1149. [CrossRef]

28. Vieira, B.C.; Fernandes, N.F.; Filho, O.A.; Martins, T.D.; Montgomery, D.R. Assessing shallow landslide hazards using the TRIGRS and SHALSTAB models, Serra do Mar, Brazil. Environ. Earth Sci. 2018, 77. [CrossRef]

29. Listo, F.D.L.R.; Gomes, M.C.V.; Vieira, B.C. Avaliação da variação do fator de segurança com o modelo TRIGRS. Rev. Bras. Geomorfol. 2018, 19. [CrossRef]

30. Nery, T.D.; Vieira, B.C. Susceptibility to shallow landslides in a drainage basin in the Serra do Mar, São Paulo, Brazil, predicted using the SINMAP mathematical model. Bull. Eng. Geol. Environ. 2014, 74, 369-378. [CrossRef]

31. Listo, F.d.L.R.; Vieira, B.C. Mapping of risk and susceptibility of shallow-landslide in the city of São Paulo, Brazil. Geomorphology 2012, 169-170, 30-44. [CrossRef]

32. Vieira, B.; Fernandes, N.; Augusto Filho, O. Shallow landslide prediction in the Serra do Mar, São Paulo, Brazil. Nat. Hazards Earth Syst. Sci. 2010, 10, 1829-1837. [CrossRef]

33. Ferreira, C.; Rossini-Penteado, D.; Brollo, M.; Picanco, J.; da Silva, M.; Guimaraes, B. Debris flow hazard and susceptibility zonation in small watersheds in Itaoca municipality, São Paulo state, Brazil. In Landslides and Engineered Slopes: Experience, Theory and Practice; CRC Press: Naples, Italy, 2016; Volume 1-3, pp. 893-900. [CrossRef]

34. Canavesi, V.; Segoni, S.; Rosi, A.; Ting, X.; Nery, T.; Catani, F.; Casagli, N. Different Approaches to Use Morphometric Attributes in Landslide Susceptibility Mapping Based on Meso-Scale Spatial Units: A Case Study in Rio de Janeiro (Brazil). Remote Sens. 2020, 12, 1826. [CrossRef]

35. Bragagnolo, L.; da Silva, R.V.; Grzybowski, J.M.V. Artificial neural network ensembles applied to the mapping of landslide susceptibility. Catena 2020, 184, 104240. [CrossRef]

36. Meirelles, E.D.O.; Dourado, F.; Costa, V.C.D. Análise multicritério para mapeamento da suscetibilidade a movimentos de massa na bacia do Rio Paquequer-RJ. GEO UERJ 2018, e26037. [CrossRef]

37. Lorentz, J.F.; Calijuri, M.L.; Marques, E.G.; Baptista, A.C. Multicriteria analysis applied to landslide susceptibility mapping. Nat Hazards 2016, 83, 41-52. [CrossRef]

38. Gomes, R.; Guimarães, R.; Osmar de Carvalho, J.; Fernandes, N.; do Amaral Júnior, E. Combining Spatial Models for Shallow Landslides and Debris-Flows Prediction. Remote Sens. 2013, 5, 2219-2237. [CrossRef]

39. Saboya, F.; da Glória Alves, M.; Pinto, W.D. Assessment of failure susceptibility of soil slopes using fuzzy logic. Eng. Geol. 2006, 86, 211-224. [CrossRef]

40. Rosa, M.L.; Sobreira, F.G.; Barella, C.F. Landslide susceptibility mapping using the statistical method of Information Value: A study case in Ribeirão dos Macacos basin, Minas Gerais, Brazil. An. Acad. Bras. Ciências 2021, 93. [CrossRef]

41. Bortoloti, F.D.; Junior, R.M.C.; Araújo, L.C.; de Morais, M.G.B. Preliminary landslide susceptibility zonation using GIS-based fuzzy logic in Vitória, Brazil. Environ. Earth Sci. 2015, 74, 2125-2141. [CrossRef]

42. Lucchese, L.V.; de Oliveira, G.G.; Pedrollo, O.C. Mamdani fuzzy inference systems and artificial neural networks for landslide susceptibility mapping. Nat. Hazards 2021, 106, 2381-2405. [CrossRef]

43. Riegel, R.P.; Alves, D.D.; Schmidt, B.C.; de Oliveira, G.G.; Haetinger, C.; Osório, D.M.M.; Rodrigues, M.A.S.; de Quevedo, D.M. Assessment of susceptibility to landslides through geographic information systems and the logistic regression model. Nat. Hazards 2020, 103, 497-511. [CrossRef]

44. Bragagnolo, L.; da Silva, R.V.; Grzybowski, J.M.V. Landslide susceptibility mapping with r.landslide: A free open-source GIS-integrated tool based on Artificial Neural Networks. Environ. Model. Softw. 2020, 123, 104565. [CrossRef]

45. de Oliveira, G.G.; Ruiz, L.F.C.; Guasselli, L.A.; Haetinger, C. Random forest and artificial neural networks in landslide susceptibility modeling: A case study of the Fão River Basin, Southern Brazil. Nat. Hazards 2019, 99, 1049-1073. [CrossRef]

46. de Brito, M.M.; Weber, E.J.; da Silva Filho, L.C.P. Análise multi-critério aplicada ao mapeamento da suscetibilidade a escorregamentos. Rev. Bras. Geomorfol. 2017, 10. [CrossRef] 
47. Strieder, A.J.; Buffon, S.A.; de Quadros, T.F.P.; Oliveira, H.R. Predicting favourable areas for landsliding through GIS modelling in Aparados da Serra (Brazil). In Geo-Environment and Landscape Evolution II: Evolution, Monitoring, Simulation, Management and Remediation of the Geological Environment and Landscape; WIT Press: Southampton, UK, 2006. [CrossRef]

48. Sbroglia, R.M.; Reginatto, G.M.P.; Higashi, R.A.R.; Guimarães, R.F. Mapping susceptible landslide areas using geotechnical homogeneous zones with different DEM resolutions in Ribeirão Baú basin, Ilhota/SC/Brazil. Landslides 2018, 15, $2093-2106$. [CrossRef]

49. Michel, G.P.; Kobiyama, M.; Goerl, R.F. Comparative analysis of SHALSTAB and SINMAP for landslide susceptibility mapping in the Cunha River basin, southern Brazil. J. Soils Sediments 2014, 14, 1266-1277. [CrossRef]

50. Sbroglia, R.; Higashi, R.; Tomazzoli, E.; Sakamoto, M.; Müller, V. Mapping of areas susceptible to landslides in the watershed of Ribeirão Baú, Ilhota, Santa Catarina, Brazil. In Landslides and Engineered Slopes: Experience, Theory and Practice; CRC Press: Naples, Italy, 2016; Volume 1-3, pp. 1799-1805. [CrossRef]

51. Martins, T.; Oka-Fiori, C.; Vieira, B.; Montgomery, D. Assessment of Lidar-derived DTMs for landslide susceptibility mapping: Application in the Brazilian subtropical forest. In Landslides and Engineered Slopes: Experience, Theory and Practice; CRC Press: Naples, Italy, 2016; Volume 1-3, pp. 1389-1392. [CrossRef]

52. Pinto, R.C.; Caneparo, S.C.; Passos, E. Avaliação Multicritério integrada aos Sistemas de Informações Geográficas para geração de cenário de suscetibilidade a deslizamentos rápidos em vertentes. In Atas das I Jornadas Lusofonas de Ciência e Tecnologias de Informação Geográfica; Imprensa da Universidade de Coimbra/Coimbra University Press: Coimbra, Portugal, 2015 ; pp. 82-107. [CrossRef]

53. Brollo, M.J.; Santoro, J.; Penteado, D.R.; da Silva, P.C.F.; Ribeiro, R.R. Itaóca (SP): Histórico de acidentes e desastres relacionados a perigos geológicos. In Proceedings of the XIV Simpósio de Geologia do Sudeste. Campos do Jord ão-SP, Brazil, 6-9 September 2015.

54. Reichenbach, P.; Rossi, M.; Malamud, B.D.; Mihir, M.; Guzzetti, F. A review of statistically-based landslide susceptibility models. Earth-Sci. Rev. 2018, 180, 60-91. [CrossRef]

55. Carrera, A.C.V.; Mendoza, M.E.; Allende, T.C.; Macías, J.L. A review of recent studies on landslide hazard in Latin America. Phys. Geogr. 2021, 1-44. [CrossRef]

56. Dietrich, W.; Montgomery, D. SHALSTAB: A Digital Terrain Model for Mapping Shallow Landslide Potential; University of California: Berkeley, CA, USA, 1998.

57. Süzen, M.L.; Doyuran, V. A comparison of the GIS based landslide susceptibility assessment methods: Multivariate versus bivariate. Environ. Geol. 2004, 45, 665-679. [CrossRef]

58. Brabb, E.E. The World Landslide Problem. Episodes 1991, 14, 52-61. [CrossRef]

59. Guzzetti, F.; Cardinali, M.; Reichenbach, P.; Carrara, A. Comparing Landslide Maps: A Case Study in the Upper Tiber River Basin, Central Italy. Environ. Manag. 2000, 25, 247-263. [CrossRef]

60. Steger, S.; Brenning, A.; Bell, R.; Glade, T. The propagation of inventory-based positional errors into statistical landslide susceptibility models. Nat. Hazards Earth Syst. Sci. 2016, 16, 2729-2745. [CrossRef]

61. Soeters, R.; Van Westen, C. Slope instability recognition, analysis and zonation. Landslides Investig. Mitig. 1996, $247,129-177$.

62. Rogers, R.; Doyle, B. Mapping of Seismically Induced Landslippage in the Benton Hills and Crowley's Ridge, New Madrid Seismic Zone, Missouri and Arkansas; Technical Report; Department of Geological Sciences and Engineering University of Missouri-Rolla: Rolla, MO, USA, 2003. 